\title{
Mutation-in-Brief
}

\section{A Novel Deletion Mutation of the Arginine Vasopressin Receptor 2 Gene in a Japanese Infant with Nephrogenic Diabetes Insipidus}

\author{
Takashi Daitsu', 2 , Junko Igaki², Masahiro Goto², and Yukihiro Hasegawa ${ }^{2,3}$ \\ ${ }^{1}$ Department of Pediatrics, Yamagata City Hospital Saiseikan, Yamagata, Japan \\ ${ }^{2}$ Division of Endocrinology and Metabolism, Tokyo Metropolitan Children's Medical Center, Tokyo, Japan \\ ${ }^{3}$ Division of Genetic Research, Tokyo Metropolitan Children's Medical Center, Tokyo, Japan
}

\section{Introduction}

Arginine vasopressin (AVP) is released from the posterior pituitary. It controls water balance homeostasis. It binds to arginine vasopressin receptor 2 (AVPR2) on the basolateral membrane of the kidney collecting duct and triggers activation of Gs proteins, which leads to increases in intracellular cAMP and the activity of protein kinase A. These increases cause trafficking of aquaporin-2 (AQP2) water channels to the apical membrane of collecting duct cells, resulting in increased water permeability and antidiuresis. The AVPR2 gene encodes a 7-transmembranespanning $\mathrm{G}$ protein-coupled receptor, which is located on chromosome Xq28. AVPR2 mutations, which are typically loss-of-function mutations, explain approximately $90 \%$ of cases of hereditary nephrogenic diabetes insipidus (NDI) (OMIM 304800). NDI is characterized by an inability to concentrate urine, resulting in excessive urine production, dehydration and thirst. Administration of exogenous AVP cannot restore

Received: March 17, 2014

Accepted: May 19, 2014

Corresponding author: Dr. Takashi Daitsu, Department of Pediatrics, Yamagata City Hospital Saiseikan, 1-3-26 Nanukamachi, Yamagata 990-8533, Japan

E-mail: tadaitsu@saiseikan.jp

This is an open-access article distributed under the terms of the Creative Commons Attribution Non-Commercial No Derivatives (by-nc-nd) License < http://creativecommons.org/ licenses/by-nc-nd/3.0/>. the normal balance of water in most patients with AVPR2 mutations.

We describe a Japanese infant with NDI who has a novel deletion mutation of the AVPR2 gene.

\section{Case Report}

A 4-mo-old boy was admitted to our hospital presenting with vomiting, failure to thrive, and hypernatremia. He was born at 40 wks' gestation, weighing $2,887 \mathrm{~g}$, and there were no problems in the perinatal period. He had no family history of NDI. At 3 mo of age, vomiting and failure to thrive began.

On admission, his body length was $59.5 \mathrm{~cm}$ (-0.5 SD) and body weight was 5,464 g (-1.2 $\mathrm{SD})$. His skin turgor was normal and anterior fontanelle was flat. The results of laboratory findings on admission are summarized in Table 1. His serum sodium level was $150 \mathrm{mEq} / \mathrm{L}$, and his chloride level was $110 \mathrm{mEq} / \mathrm{L}$. His venous gas values were within normal limits. His urine volume was $1,085 \mathrm{~mL} / \mathrm{d}\left(3,616 \mathrm{~mL} / \mathrm{m}^{2} / \mathrm{d}\right)$, and his urine osmolality was low, in spite of high serum osmolality and an elevated AVP level.

He was diagnosed as having congenital NDI. Management was started by intravenous and oral fluid administration, followed by sodium restriction $(1.0 \mathrm{mEq} / \mathrm{kg} / \mathrm{d})$ and administration of oral hydrochlorothiazide $(2 \mathrm{mg} / \mathrm{kg} / \mathrm{d})$. Water intake and urinary volume before the therapies were about $1,400 \mathrm{~mL} / \mathrm{d}$ and about $1,000 \mathrm{~mL} / \mathrm{d}$, 
Table 1 Laboratory data on admission

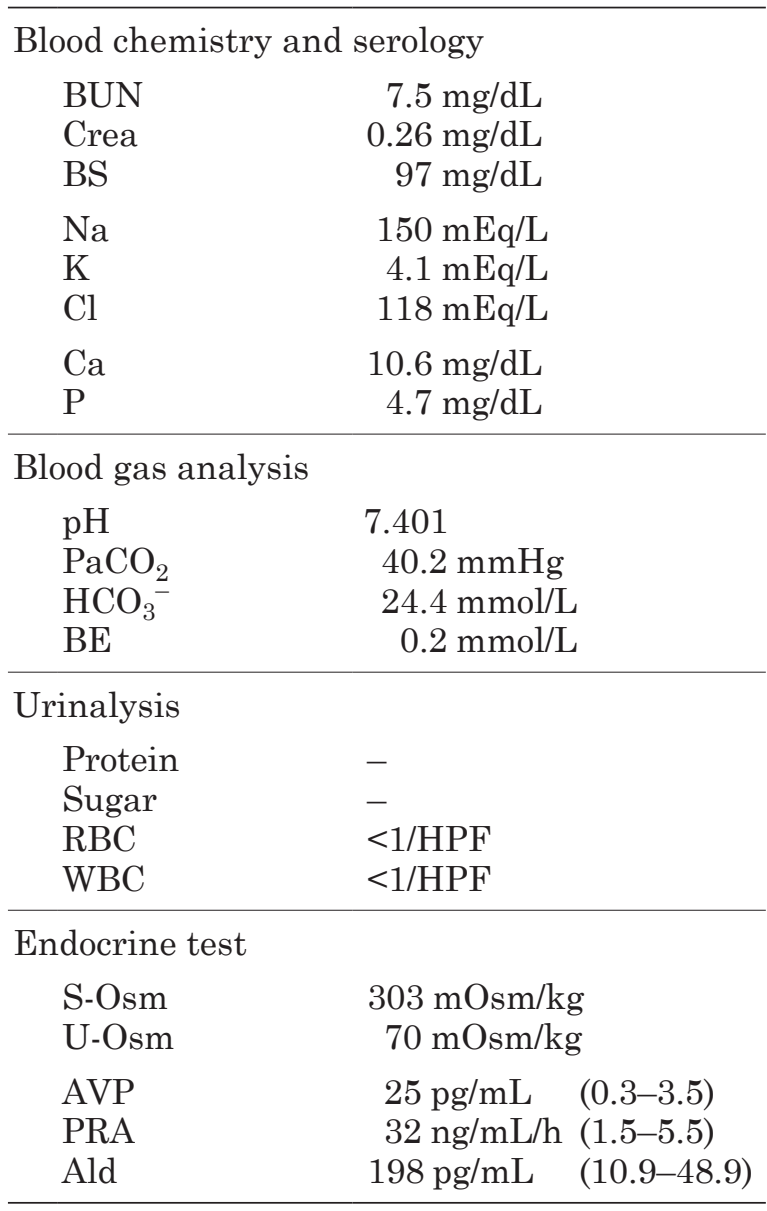

S-Osm, serum osmolality; U-Osm, urine osmolality; PRA, plasma renin activity; Ald, Aldosterone.

respectively. After therapy, they were about $1,100 \mathrm{~mL} / \mathrm{d}$ and about $800 \mathrm{~mL} / \mathrm{d}$, respectively. Two weeks after admission, his levels of serum electrolytes were normal.

\section{Mutational Analysis}

Informed consent, based on the Helsinki Final Act of 1975, for a mutational analysis was obtained from the patient's parents. Genomic DNA was extracted from white blood cells. PCR and direct sequencing were conventionally performed. Analysis of the AVPR2 gene revealed a novel one-nucleotide deletion at position 368 (c.368delT) (Fig. 1). This mutation resulted in a

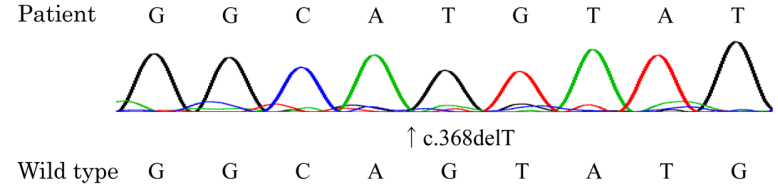

Fig. 1. Sequence of the AVPR2 gene in the patient. The patient had a one-nucleotide deletion at position 368 (c.368delT). An arrow indicates the delation site.

frameshift and premature stop codon (M129*) in the third transmembrane domain. The analysis of the AQP2 gene was negative. Specimens from the parents were not available for analysis.

\section{Discussion}

At present, according to the Human Gene Mutation Database (HGMD; www.hgmd.cf.ac. uk), more than two hundred mutations in the AVPR2 gene have been detected, including nonsense mutations and frameshift mutations leading to stop codons. Although a correlation between genotype and phenotype has not been previously reported, partial correlation is thought to be present. For example, a large number of these mutant receptors fail to fold properly and therefore are not routed to the cell surface (1), resulting in a complete inability to concentrate urine.

The present patient had a novel onenucleotide deletion at position 368 (c.368delT). This mutation resulted in a frameshift and premature stop codon (M129*) in the third transmembrane domain.

We consider that the M129* mutation is a causative mutation of NDI. There are at least 18 nonsense mutations beyond this codon (M129*), namely, W156*, W164*, S167*, Q180*, W193*, W200*, Q225*, E231*, E242*, W284*, W293*, W296*, L312*, W323* and R337*, and at least 28 types of deletion mutation introducing a stop codon beyond this codon (M129*). A nonsense mutation of the C-terminal intracellular tail $\left(\mathrm{R} 337^{*}\right)$ is a cause of NDI (2) and is predicted 
to produce a truncated mutant protein, which was reported not to be transported to the plasma membrane (3). The mutation in our case is also predicted to produce a truncated protein that is shorter than the R337* mutant protein.

\section{References}

1. Morello JP, Salahpour A, Laperrière A, Bernier V, Arthus MF, Lonergan M, et al. Pharmacological chaperones rescue cell-surface expression and function of misfolded V2 vasopressin receptor mutants. J Clin Invest 2000;105: 887-95. [Medline] [CrossRef]

2. Moses AM, Sangani G, Miller JL. Proposed cause of marked vasopressin resistance in a female with an X-linked recessive V2 receptor abnormality. J Clin Endocrinol Metab 1995;80: 1184-6. [Medline]

3. Sadeghi HM, Innamorati G, Birnbaumer M. An $\mathrm{X}$-linked NDI mutation reveals a requirement for cell surface V2R expression. Mol Endocrinol 1997;11: 706-13. [Medline] [CrossRef] 